\title{
Crossing the border \\ Historical and linguistic divides among the Bunaq in central Timor
}

\author{
ANTOINETTE SCHAPPER
}

\begin{abstract}
The Bunaq are a Papuan language-speaking people straddling the border of Indonesian West Timor and independent East Timor. This paper looks at the history of the Bunaq as a "border" people in Timor. "Border" is interpreted here in two ways, as referring to: (i) a political division, the boundary line separating one country from another, and (ii) a linguistic division, the distinguishing line between Papuan and Austronesian languages. I examine the effect that the Bunaq position at the political and linguistic borders of Timor has had on the people and their language.

KEYWORDS

Bunaq, Timor, border disputes, linguistic borrowing and change.
\end{abstract}

\section{INTRODUCTION ${ }^{1}$}

The island of Timor is located at the eastern end of the Minor Sundic Island chain in east Nusantara. It is unique in the region for the fact that it has been a divided island and a source of dispute for centuries. Today Timor is split roughly in the middle between independent East Timor and Indonesian West Timor. The modern division of the island has its roots in colonial borders drawn following more than a century of intermittent dispute and negotiation between the Portuguese and Dutch.

Timor is not only unusual in the region for its political division, but also for its linguistic division. As in much of the Philippines, western Indonesia and the Pacific, east Nusantara is dominated by languages of the Austronesian family (Adelaar 2005). By contrast, Timor is home to Papuan (or non-Austronesian

1 This research was supported by grant 08-EuroBABEL-OP-O25 from De Nederlandse Organisatie voor Wetenschappelijk Onderzoek.

ANTOINETTE SCHAPPER took her PhD degree at the Australian National University with a grammar of the Papuan language Bunaq spoken in Timor. She is currently a post-doctoral researcher in the Alor-Pantar project at Leiden University, working on several Papuan languages of central Alor. Antoinette Schapper may be contacted at: a.c.schapper@hum.leidenuniv.nl.

(C) 2011 Faculty of Humanities, University of Indonesia 
languages; Foley 1986) as well as Austronesian languages (Map 1). There are four Papuan language-speaking groups split into two regions of the island. ${ }^{2}$ (i) the Fataluku, Makasae and Makalero who are located in a contiguous area at the eastern extreme of the island, and (ii) the Bunaq who occupy a large area in central Timor, straddling the modern border and surrounded on all sides by Austronesian languages.

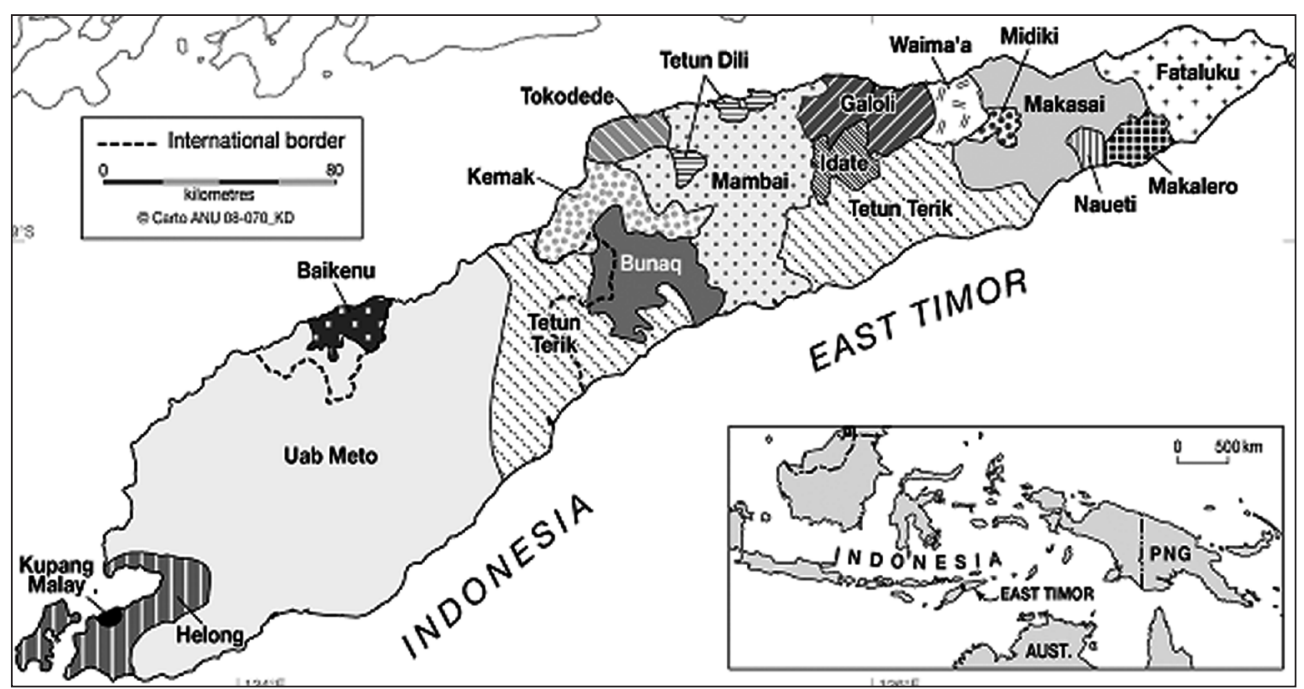

Map 1. Austronesian languages in Timor (Map by the author).

This paper looks at the history of the Bunaq as a "border" people in Timor. "Border" is interpreted here in two ways, as referring to: (i) a political division, the boundary line separating one country from another, and (ii) a linguistic division, the distinguishing line between Papuan and Austronesian languages. I examine the effect that the Bunaq's position at the political and linguistic borders of Timor has had on the people and their language. In § 2 I look at the Bunaq as an ethno-linguistic group that has both shaped and been shaped by the colonial border and subsequent conflicts over the border. In $\S 3$ I consider the Bunaq language as a linguistic hybrid which blurs the borders between the Austronesian and Papuan distinction. Finally, I summarise the discussion in $\S$ 4 , highlighting that the Bunaq retain a notion of their coherence as a linguistic community despite being divided by a national frontier.

\section{LIVING ON THE EDGE: THE BUNAQ ON THE TIMORESE BORDER}

The Bunaq-speaking area extends in the north from Maliana down to portions of the southern coast in East Timor; it stretches west from the eastern edges

2 More distant relatives are found on the islands of Alor and Pantar to the north of Timor. Together the Papuan languages of Timor-Alor-Pantar (TAP) form a language family that differentiated sometime before the Austronesian arrival in the region in the late Holocene. The wider genetic relations of the TAP language family to other Papuan languages of the New Guinea mainland, such as the Trans-New Guinea family, remain highly speculative. 
of southern Belu regency in West Timor into the western edge of Manufahi sub-district in East Timor (Map 2). The modern dispersal of Bunaq speakers reflects a long history of movement and expansion due to political turmoil and upheaval (Schapper forthcoming). These conflicts closely link the Bunaq to the Timorese border in two ways.

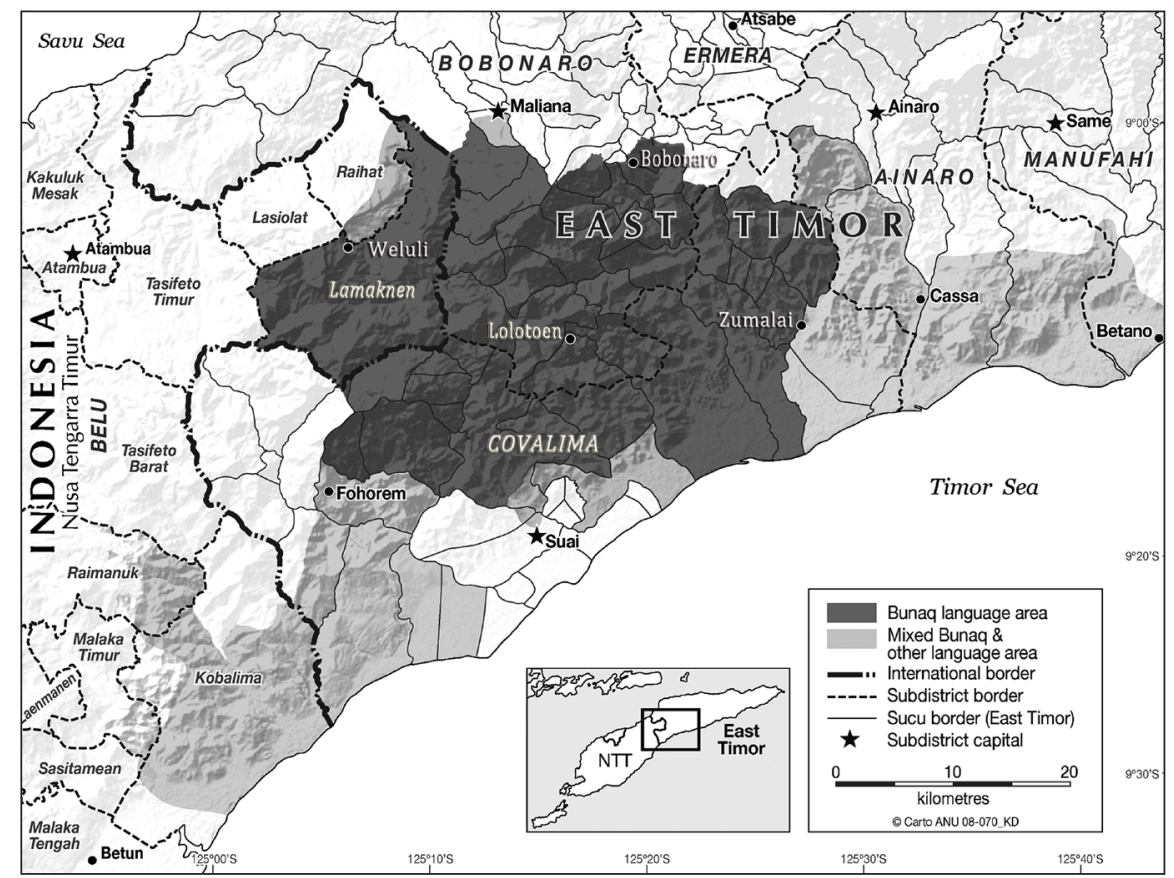

Map 2. The Bunaq-speaking area (Map by the author).

On the one hand, conflicts amongst the Bunaq have had a formative effect on the partitioning of Timor. Before the establishment of the first European sandalwood traders in the sixteenth century, Timor was divided into many traditional states. Colonial demarcations of territory in Timor were arrived at in part by listing the various traditional states under each of the colonial powers' imagined authority. Yet, the borders of these states were not fixed; so the borders between Dutch and Portuguese Timor were subject to the vagaries of local claims to territory and the consequent to-ing and fro-ing of land between native states.

On the other hand, the presence of the border has had a significant impact on the shape of the Bunaq area. From the colonial era onwards, Bunaq groups have crossed the border from East Timor into West Timor in search of asylum from conflict. As a result, the Bunaq now occupy vast tracts of land in West Timor in which Austronesian peoples are traditionally settled.

Following a brief overview of the formation of the colonial border in $\S$ 2.1, I discuss the relation between the Bunaq and the border in the Maucatar region in the colonial period (\$ 2.2), in World War II ( $(2.3)$, and in the postcolonial period (§ 2.4). 


\subsection{THE COLONIAL PARTITIONING OF TIMOR ${ }^{3}$}

The Portuguese - largely consisting of mestiços, so-called Topasses or "black Portuguese" (Boxer 1947) - at first established themselves north of Timor on Solor island in the mid-sixteenth century. From mid-1600, they extended their influence and control over much of the mountainous sandalwood-growing interior of Timor (Hägerdal 2007). The Dutch arrived in Timor in the midseventeenth century and established a garrison in Kupang, the capital of today's province of Nusa Tenggara Timur. Initially, they attempted to gain influence over parts of the interior, but without success.

It was not until 1749 that the Portuguese dominance in Timor came to an end, when an attack against the Dutch post in Kupang was a spectacular failure. At this, numerous traditional states in the west Timorese area fell away from the Portuguese and sided with the Dutch as part of a formal contract with the Dutch East Indies company signed in 1756 (Roever 2002). Whilst borders remained vague, this event set the stage for the primary east-west division of Timor between the Portuguese and Dutch.

The earliest attempt to fix a border was in 1816 when the Dutch determined to define their areas of supposed control in relation to the Portuguese. A series of border disputes ensued: the Portuguese claimed a large portion of what is today West Timor, while the Dutch laid claim to stretches of land on the northern and southern coasts of what is now East Timor. In particular, the Dutch claimed Maubara, a region on the north-central coast, and Maucatar, a small enclave located near Suai, both parts of today's East Timor. The Portuguese made counter-claims for the Noimuti and Oecussi enclaves in the western part of the island.

In 1851 the Dutch offered to purchase all Portuguese claimed lands. The Portuguese declined but agreed to establish borders between the respective colonial powers' areas. A treaty of demarcation and exchange of territory was negotiated in 1854 and subsequently ratified in 1859 . On Timor, the significant details of the treaty were: (i) the Portuguese were ceded Maubara, and their claims on the Oecussi and Noimuti enclaves were recognised, and (ii) the Dutch were ceded the Maucatar enclave. However, fixed borders had still not been defined.

A series of conventions in 1893,1904 and 1913 took place in order to achieve a more precise demarcation of the border. The 1893 convention agreed that a better demarcation was required. The 1904 convention eliminated the enclaves, ceding Noimuti to the Dutch and Maucatar to the Portuguese, and set forth the remaining border in terms of landmarks and, in their absence, thalwegs. The Portuguese were able to retain the Oecussi enclave, arguing that, not being land-locked, it did not constitute a true enclave. The 1913 convention was an agreement to submit the dispute over a few remaining borders, mainly for Oecussi, to the International Court of Arbitration.

3 The various border negotiations are discussed in detail in Heyman (1895) and Ezerman (1917). The texts of the various Portuguese-Dutch treaties and conventions are given in Krieger (1997: 1-17). 
The border which was finally fixed by this court in 1914 became that which divided the island at independence from the colonial powers. In 1949 West Timor became part of Indonesia, and in 1975 East Timor became independent, then part of Indonesia, and finally in 2002 independent once more.

\subsection{THE SHIFTING BORDER IN CENTRAL TIMOR}

The central border which was eventually defined in these long and drawn out negotiations ran - and still runs today - in part though the Bunaq area. The treaty of 1859 defined the centre line between areas which were to be considered henceforth as either Dutch or Portuguese territory by naming native states and in particular Bunaq states (Farram 1999). Bunaq states with allegiance to the kingdom of Wehali centred in the south-western Tetun area of Dutch Timor were listed as Dutch; those aligned with the kingdom of Likosaen centred in the north-eastern Tokodede area of Portuguese Timor were listed as Portuguese.

However, the small Bunaq native states within these larger alliances were far from stable. From 1897 to 1914, this Bunaq border area was the stage for numerous disputes and several armed clashes between the Dutch and Portuguese. Underlying the territorial tensions of the colonial powers were conflicts between several native Bunaq states of various sizes, most notably Lamaknen, Tahakay, Lamakhitu, Lakmaras, and Maucatar (Map 3).

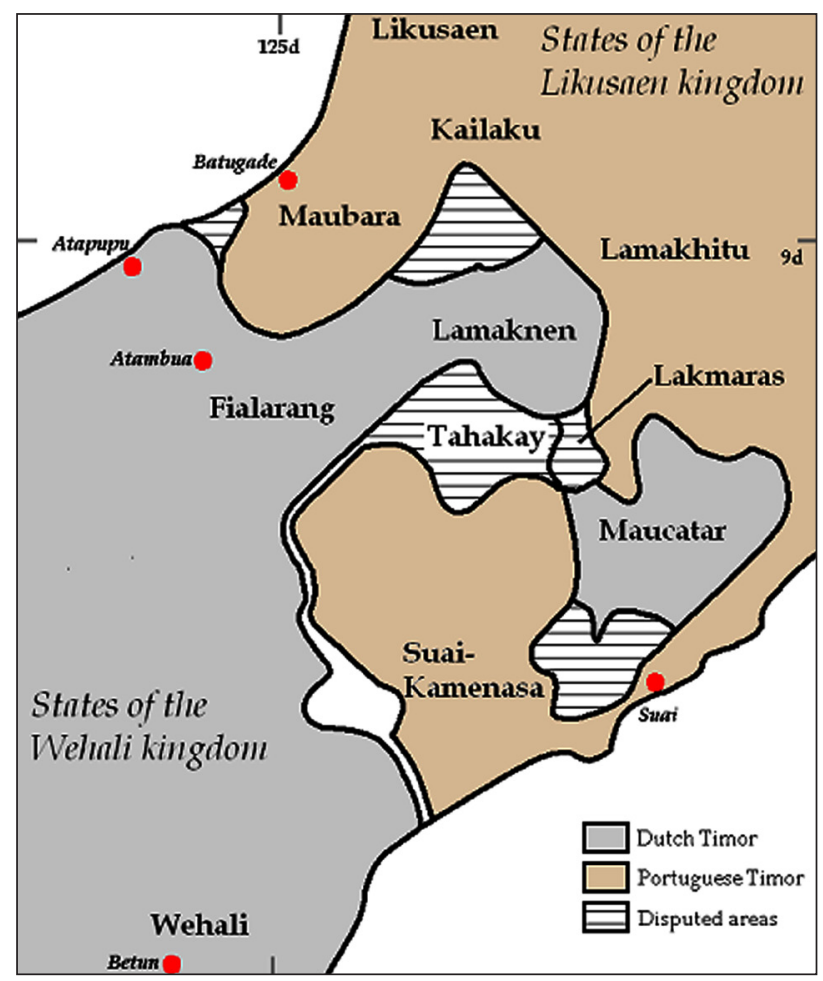

Map 3. The Bunaq border area and disputed areas (Map by the author). 
For instance, the Bunaq state of Tahakay had been declared Portuguese under the 1859 treaty. Tahakay had, however, subsequently become a part of Lamaknen, located in Dutch Timor. As a result, Tahakay was transferred from the Portuguese to the Dutch in the 1904 treaty. The Portuguese, enraged at the loss due to shifting local politics, attempted to head off the transfer in the negotiations of June 1902 by demanding all of the central Dutch territory protruding eastwards into Portuguese Timor. ${ }^{4}$ The Portuguese claims were warned off by local chieftains who refused to pass under the sovereignty of Portugal.

The Dutch claims to Maucatar similarly hinged on the affiliation of local states. In the 1859 treaty, Maucatar was described as an enclave. Nevertheless, in later negotiations the Dutch claimed Maucatar was not in fact an enclave, but adjoined to the other Dutch territory by the state of Lakmaras, a part of Lamaknen. The Portuguese counter-sued that Lakmaras had passed from the Dutch state of Lamaknen to the Portuguese state of Lamakhitu, another Bunaq state in the area of Bobonaro. This claim meant that Maucatar was now a land-locked enclave and under the 1904 agreement must be ceded to Portugal (Sowash 1948).

Yet the final transfer did not transpire without conflict. During 1897, a series of clashes between Portuguese and Dutch forces took place over Lakmaras (Pélissier 1996: 174 and further). Several soldiers were killed and others captured. Even following the 1904 agreement to cede Maucatar, the dispute was drawn out. In 1911, when Portuguese troops moved into Maucatar, they were met by Dutch forces. Clashes continued throughout 1911, before the Dutch agreed to withdraw as per the agreement of 1904. During the fighting of 1911 and following the ceding of the enclave to Portugal, some 5,000 Maucatar Bunaq decamped to Dutch Timor into the Tetun area of what is now southern Belu in Indonesian West Timor. Today, the descendents of these Bunaq proudly declare themselves the first refugees from East to West Timor.

\subsection{THE BORDER AND WORLD WAR II}

The Japanese occupation of Timor has also had a formative effect on the Bunaq area. The Japanese invaded Timor on 20 February 1942 and within days had overwhelmed the small force of Australian and Dutch troops. Some of these troops managed to evade capture and withdrew into the mountains, from where they waged a guerrilla campaign against the Japanese. The guerrillas were based in the mountainous Bobonaro area of East Timor in the heart of the Bunaq area, and were assisted by them (Callinan and Shute 1953).

In August 1942, the Japanese carried out a series of reprisals against the Bunaq population in the area of Bobonaro who had assisted the guerrillas. Tens of thousands are believed to have been killed and many others displaced in a massive collective flight out of Bobonaro away from the Japanese army. These

4 In a review of the negotiations in the final award of the Court, the arbitrator refers to this region as "all the part of the territory of Fialarung, situated east of the river Mota Bankarna" (International Court of Arbitration 1914). 
descendents of the displaced Bunaq are still found today in two places: (i) in the upland parts of the $\operatorname{sucos}^{5}$ of Foholulik and Lalawa, just east of the border with Indonesia, and (ii) in disparate settlements of the Kobalima, Malaka Timur and Raimanuk sub-districts just west of the border (Woertelboer 1955).

Not all Bunaq had collaborated with the Dutch and Australian forces; some had sided with the Japanese. According to oral tradition, these Bunaq feared reprisals for their support of the Japanese following the end of World War II. In 1945 they decamped from their villages in East Timor to across the border, arriving in West Timor's Lamaknen. After a grant of land from the raja of Belu, these post-war refugees established the village Lakus, which remains to this day in a valley of Bunaq Lamaknen.

\subsection{THE BORDER FROM 1975 ONWARDS}

The Timorese border was host to repeated conflicts between 1975 and 1999. In this period, multiple waves of refugees flooded across the border from East Timor into West Timor pursued by militias and the threat of armed violence. Being located on the border, the Bunaq felt the full force of these upheavals, with whole villages being swept away before the violent storm at different times. The full extent of the disruption and displacement experienced by the Bunaq cannot be chronicled here. Instead I provide a brief overview of the major events.

East Timor began the process of decolonisation in Portugal in 1974. By mid-1975, the main political parties - Frente Revolucionária de Timor-Leste Independente (Fretilin), União Democrática Timorense (UDT) and Associação Popular Democrática Timorense (Apodeti) - had become embroiled in a series of political crises. On August 11 UDT initiated a coup d'état in an attempt to crush mounting support for Fretilin. Fretilin responded with a general call to arms. At this, many UDT and Apodeti supporters fled to West Timor fearing that they would become the target of inter-party violence.

Among these were numerous Bunaq villages extending along the border, such as Odomau, Holpilat, Lela, Aitoun, Beidasi, Holsa, Memo and Raifun (CAVR 2005: 11). Whilst many returned to East Timor, large numbers of Bunaq settled permanently amongst the Bunaq villages of West Timor. At the end of August, the conflict escalated further when Fretilin stationed troops from its military wing, Falintil, along the border to stop opposition party leaders and their supporters from fleeing to West Timor. Bunaq villages on both sides of the border were destroyed in the ensuing clashes. For instance, the Bunaq village of Henes on the West Timorese side of the border was burnt to the ground in 1975 never to be re-established.

Indonesian forces arrived in the Timorese border area in late 1975. Their steady movement into East Timor was accompanied by a rapid dissolution of village groups in the Bunaq area, as people sought cover in the forest. The first group of Bunaq left the forest to live in Bobonaro on 3 February 1976. The 
last groups to surrender were the Bunaq people, some of whom held out in the forest for more than three years (CAVR 2005: 25). The extended disruption of village life meant that many communities never wholly re-formed, but gradually resettled in disparate locations within the Bunaq area up to 1999.

On August 301999 the majority of East Timorese voted for independence from Indonesia. Amongst those who had supported integration into Indonesia, there was a general rush to the border. The first refugees entered West Timor at the beginning of September and continued to arrive in a steady stream in the next weeks (CAVR 2005: 74). On this occasion also many Bunaq suffered directly in the upheaval. Throughout the Bunaq area, pro-independence militias patrolled the border cutting off refugees before they crossed into West Timor. At the same time, pro-integration militias forcibly removed Bunaq from their villages and brought them across the border to West Timor, and prohibited return to East Timor. Those Bunaq who stayed set up rambling bush huts on roadsides throughout Lamaknen, many of which remain to this day.

\subsection{SUMMARY}

The Bunaq in central Timor have had a significant impact on the border dividing the island. The internal alliances and conflicts of Bunaq states in the colonial era influenced the drawing of boundaries and caused protracted border tensions between the colonial powers. What is more, the Bunaq's position on the border has contributed to their scattered dispersal across a larger portion of central Timor. Since the setting of the border between east and west, successive waves of Bunaq have been compelled by political upheaval to cross the border into West Timor.

\section{CROSSING THE BORDER OF LINGUISTIC AFFILIATION}

The Bunaq are linguistically isolated in central Timor; their language is widely recognized as "different" both by the Bunaq themselves and their Austronesian neighbours. Today, all adult Bunaq speak one or more Austronesian language, typically Tetun and/or Malay, but often also Kemak or Mambai depending on the region. By contrast, Austronesian language speakers in central Timor almost never learn Bunaq.

Whilst their linguistic non-conformity has set them apart to some degree, it has also led to an inclusive cultural attitude on the part of the Bunaq. Indeed, borrowing and adaptation from Austronesian language and society pervades every aspect of the Bunaq language (see, for example, Berthe 1959, 1963). The sheer number of foreign words and constructions in Bunaq points not merely to millennia of Austronesian contact and multilingualism on the part of the Bunaq, but to their readiness to borrow in order to make their language's stock richer and more subtle. Yet, the frequently novel manner of the integration of foreign words and constructions into the Bunaq language shows not simply accommodation of an alien power, but a mixture of covert resistance and inspired collaboration. 
In the following sections, aspects of Bunaq's "mongrel" character will be illustrated. In § 3.1 I look at the different layers of lexical borrowing which are present in Bunaq. In $\S 3.2$ I overview the different types of grammatical borrowing in Bunaq.

\subsection{LEXICAL BORROWING}

Lexical borrowing refers to the adoption of individual words or even large sets of vocabulary items from another language. In Bunaq, lexical items borrowed from Austronesian account for over $30 \%$ of the modern lexicon. This includes many supposedly borrowing-resistant items of "core vocabulary": on a basic 200 item Swadesh wordlist 40 items are Austronesian in origin. ${ }^{6}$ There are two layers of borrowing from neighbouring Austronesian languages that can be distinguished in the Bunaq lexicon.

\subsubsection{CENTRAL-NORTH BORROWING}

The oldest layer of Austronesian borrowing in Bunaq comes from Bunaq's Austronesian neighbours, Kemak, Tokodede, Dawan and Mambai, or their forerunners. Lexemes from these languages are concentrated in several semantic domains.

Bunaq has borrowed numerous kin terms from Austronesian languages (Table 1). Borrowings typically refer to male roles. ${ }^{7}$ This might suggest that linguistic adoptions were fuelled by exogenous marriages with Austronesian speaking males. Such a pattern would fit with the Bunaq's predominant matrilineal kin structure (Friedberg 1980), as it would allow men to be brought in from outside without disrupting lines of descent and inheritance. The one borrowed female term, nana 'older sister', is also an adoption from Austronesian culture. Age-differentiated sibling kin terms reflect a peculiarly Austronesian interest in precedence, a feature which is not typical of Papuan societies (McWilliam 2007).

6 Swadesh (1955) proposed that all languages, irrespective of cultural differences, had words for 100 or 200 key concepts that were unlikely to be borrowed from other languages. This "core vocabulary" was designed to encompass concepts common to every human language (such as personal pronouns, body parts, heavenly bodies, verbs of basic actions, numerals, etcetera). Whilst the concept of unborrowable vocabulary has been emphatically refuted, Swadesh's basic list provides a preliminary measure for assessing the extent of lexical borrowing in language.

Bunaq terms for female roles do not reflect Austronesian sources: for example, Bunaq eme 'mother' $\neq$ Tet./Kem./Mam. ina 'mother'; Bunaq pana 'woman' < proto-TAP *panV 'woman', $\neq$ Tet. feto 'mother', Kem./Mam. hine 'woman'. 


\begin{tabular}{cllll}
\hline Bunaq & & Central Timor & \\
\hline kaqa & 'older brother' & Kmk. & kaqa-r & 'older brother' \\
nana & 'older sister' & Kmk. & 'older sister (of \\
tata & 'ancestor' & Kmk. & $\begin{array}{l}\text { male)' } \\
\text { tata-r 'grandparent, } \\
\text { ancestor' }\end{array}$ \\
mone & 'man' & Daw. & mone 'man' \\
& & Tet./Kmk./Mam. & mane 'man' \\
ama & 'father' & Tet./Mam./Kmk. & ama 'father' \\
baba & 'maternal uncle' & Daw. & baba- 'males of \\
& & & & $\begin{array}{l}\text { preceding } \\
\text { generation of } \\
\text { wife's lineage' }\end{array}$ \\
& & & &
\end{tabular}

Table 1. Borrowed kin terms.

Bunaq numerals show significant influence from Austronesian (Table 2). The quinary (base-5) system originally present in TAP languages (Stokhof 1975) is replaced in Bunaq with Austronesian numerals from 7 to 9. Decimal numeral bases above 10 are also borrowed from Austronesian.

\begin{tabular}{cllll}
\hline Bunaq & \multicolumn{5}{c}{ Central Timor } \\
\hline hitu & 'seven' & Tet./Kmk./Tok. & hitu 'seven' \\
walu & 'eight' & Tet./Kmk./Tok. & walu 'eight' \\
siwe & 'nine' & Tet./Kmk./Tok. & siwe 'nine' \\
lihur & 'thousand' & Kmk. & rihur 'thousand' \\
atus & 'hundred' & Tet./Mam & atus 'hundred' \\
& & & & \\
\hline
\end{tabular}

Table 2. Borrowed numerals.

The Austronesian borrowings of this layer encompass basic nouns and verbs of the everyday world. Examples are given in Table 3. 


\begin{tabular}{cllll}
\hline Bunaq & \multicolumn{3}{l}{ Central Timor } \\
\hline taho' & 'low cloud' & Kmk. & taho' & 'cloud, mist' \\
huan & 'heart' & Kmk. & huan & 'heart' \\
& & Mam. & hua & 'heart' \\
hul & 'moon' & Mam. & hul & 'moon' \\
& & Kmk. & hulo & 'moon' \\
haru & 'shirt' & Kem./Mam. & haru & 'shirt' \\
si & 'meat' & Mam. & si sis & 'meat' \\
& & Kmk. & si & 'meat' \\
le & 'light' & Mam. & le $\sim$ lel & 'sun' \\
to & 'year' & Mam. & to $\sim$ ton & 'year' \\
& & Kmk. & to & 'year' \\
& & & & \\
\hline botus & 'meet' & Kmk. & botus & 'meet' \\
toek & 'speak, talk' & Kmk. & toek & 'speak, talk' \\
tilu' & 'stay, rest' & Kmk. & tilu' & 'stay, rest' \\
hui & 'wild' & Kmk./Mam. & hui & 'wild' \\
lulai & 'move' & Mam. & lolai & 'walk' \\
loi & 'good' & Kmk. & mloi & 'good' \\
& & Tok. & bloi & 'good' \\
doq & 'cut off' & Mam. & do & 'cut, hack' \\
& & & & \\
\hline
\end{tabular}

Table 3. Examples of borrowed common nouns and verb.

\subsubsection{TETUN BORROWING}

The linguistic map of Timor bears witness to the fact that, sometime before the established of the European colonies on Timor, the Tetun people had risen to significance in central Timor. They dispersed northwards into the mountainous interior and eastwards along the south coast from their traditional base on the south-central coast in the area of Wehali (Fox 2003: 20-21). Concomitant to the Tetun expansion was their increased ability to assert influence on other groups. The consequences of this are seen in the sheer quantity of Tetun vocabulary pervading Bunaq.

In describing class, rank and ritual, we find almost exclusively Tetun terminology used in Bunaq. Examples are given in Table 4. Bunaq parallel ritual language is also deeply reliant on loan words from Tetun to create the parallel pairs that run across half-lines (see Schapper 2010: 24-16). 
Tetun borrowings are found in all open word classes of the Bunaq language. Many modern material culture items in Bunaq are taken from the Tetun (for example, B. sabi 'key' < T. sabi 'key', B. loron 'road' < T. luron 'road', B. tudi' 'knife' < T. tudik 'knife'). The natural world is also well-represented amongst the Tetun borrowings, including insects (for example, B. keboko' 'grub' < T. kebeko 'caterpillar', B. labarain 'spider' < T. labadain 'spider', B. susu' 'mosquito' < T. susuk 'mosquito') and reptiles (for example, B. lafae' 'crocodile' < T. lafaek 'crocodile', T. teki 'lizard sp.' < B. teki 'lizard sp.'), plants (for example, B. bakat 'plant sp.' < T. bakat 'plant sp.', kakibat 'banyan' < kakibat 'banyan') and body parts (for example, B. sakan 'upper leg' < T. sakan 'thigh', B. uat 'vein, tendon' < T. uat 'vein'). A great many Bunaq verbs also have Tetun origins. The borrowings are dispersed throughout the verbal lexicon but have particularly strong concentrations in reference to states (for example, B. baruq 'bored' < T. baruk 'angry, bored', B. bokul 'fat, healthy' < T. bokur 'fat', B. mamal 'soft' > T. mamar 'soft', B. meak 'be reddish-brown' < T. meak 'rust') and cognitive and perceptual events (for example, B. me' $i$ 'dream' < T. mehi 'dream', B. piar 'believe' < T. fiar 'believe', B. tara 'know' < T. tada 'know', B. teke' 'look at, examine' < T. hateke 'see').

\begin{tabular}{|c|c|c|c|}
\hline Bunaq & & Tetun & \\
\hline$b e i$ & 'grandparent, ancestor' & $b e i$ & 'grandparent' \\
\hline banin & 'in-laws' & banin & 'in-laws' \\
\hline dato & 'noble' & dato & ‘noble’ \\
\hline denu & 'commoner' & renu & 'commoner' \\
\hline lisan & 'personality, trait' & lisan & 'tradition, custom' \\
\hline loro & 'king' & loro & 'king, sun' \\
\hline lok & 'offer betel' & lok & 'offer in hospitality' \\
\hline$n a^{\prime} i$ & 'royal' & $n a^{\prime} i$ & 'royal' \\
\hline teberai' & $\begin{array}{l}\text { 'dance to drum (of } \\
\text { women)' }\end{array}$ & tebedain & 'dance to drum' \\
\hline tei & $\begin{array}{l}\text { 'dance with feet } \\
\text { stomping' }\end{array}$ & teik & 'make noise with feet' \\
\hline pa'ol sau & $\begin{array}{l}\text { 'festival lifting ban on } \\
\text { corn' }\end{array}$ & sau & $\begin{array}{l}\text { 'lift a prohibition or } \\
\text { ban' }\end{array}$ \\
\hline ukon & 'govern' & ukun & 'govern'e' \\
\hline ukur & 'power, authority' & ukur & $\begin{array}{l}\text { 'ritual, ceremony', } \\
\text { 'cords linking edges of } \\
\text { loom' }\end{array}$ \\
\hline uma metan & 'ruling house' & uma metan & $\begin{array}{l}\text { 'black house' (used in } \\
\text { scared contexts) }\end{array}$ \\
\hline
\end{tabular}

Table 4. Borrowed class, rank and ritual lexicon in Bunaq. 


\subsection{GRAMMATICAL BORROWING}

Bunaq is appreciably different from the Austronesian languages in Timor in terms of basic grammatical structure. Table 5 presents an overview of the basic syntactic (or word order) differences between these two.

\begin{tabular}{lll}
\hline & Timor Austronesian & Bunaq \\
\hline Agreement on verb & Subject agreement & Object agreement \\
Word order & SVO & SOV \\
Adpositions & Prepositions & Postpositions \\
Conjunctions & Clause-initial & Clause-final \\
& & \\
\hline
\end{tabular}

Table 5. Comparison of basic grammatical differences.

Despite the substantial differences in basic structure, Bunaq has incorporated multiple grammatical morphemes and constructions from Austronesian languages. This has been achieved by re-analysing Austronesian structures to fit existing Bunaq structures (for example, adaptation of Tetun verbal inflections discussed in § 3.2.1), by adapting its own structure (for example, the calquing discussed in § 3.2.2), and by accommodating Austronesian structures to exist alongside Bunaq structures (for example, the bracketing constructions discussed in $§ 3.2 .3$ ).

\subsubsection{AdAPTATION OF TETUN VERBAL INFLECTIONS}

In Bunaq and Tetun Terik, agreement prefixes appear on the verb. In Tetun, a verbal prefix co-indexes the clausal subject (Van Klinken 1999: 172, illustrated in 1). In Bunaq, a verbal prefix co-indexes the clausal object (Schapper 2010: 336). Bunaq also has different prefixes depending on the animacy of the object: animate third person objects are marked with $g V-(2 a)$, while inanimate third person objects are marked with $h V-(2 b)$. This pattern is not present in Tetun.

Tetun

$\begin{array}{ll}\text { 1. a. Ha'u k-aré Markus } & \text { b. } \mathrm{Ha}^{\prime} u \text { k-aré uma. } \\ \text { 1sG 1sG-see Markus } & \text { 1sG 1sG-see house } \\ \text { 'I see Markus.' } & \text { 'I see a house.' }\end{array}$

Bunaq

$\begin{array}{ccccl}\text { 2. a. } & \text { Neto Markus } & \text { g-azal. } & \text { b. } & \text { Netodeu h-azal } \\ \text { 1sG } & \text { Markus } & \text { 3AN-see } & & \text { 1sG house 3INAN-see } \\ & \text { 'I see Markus.' } & & & \text { 'I see a house.' }\end{array}$

Tetun verbs with initial / h/ lose their first consonant where subject prefixes mark the verb. First and second person plural subjects are not marked 
by an agreement prefix and the h- initial root is used in these contexts. Bunaq copies this pattern on borrowed h-initial Tetun verbs. It replaces the Tetun subject prefixes with its own object prefixes and reanalyses the initial /h/ of the Tetun root as a third person inanimate prefix like that in (2b). Bunaq similarly reanalyses the Tetun causative prefix $h a$ - as part of this inflectional paradigm. Table 6 illustrates the Tetun prefixation pattern and the re-analysed Bunaq pattern on the Tetun verb hisik 'sprinkle'.

\begin{tabular}{|c|c|c|c|c|c|}
\hline \multicolumn{3}{|l|}{ Tetun } & \multicolumn{3}{|l|}{ Bunaq } \\
\hline $1 \mathrm{sg}$ & k-isik & 'I sprinkle' & 1EXCL & $n$-isik & $\begin{array}{l}\text { 'sprinkle } \\
\text { me/us' }\end{array}$ \\
\hline $2 \mathrm{sg}$ & m-isik & $\begin{array}{l}\text { 'you } \\
\text { sprinkle' }\end{array}$ & 1INCL/2 & $\varnothing$-isik & $\begin{array}{l}\text { 'sprinkle } \\
\text { us/you' }\end{array}$ \\
\hline 3SG & n-isik & $\begin{array}{l}\text { 's/he } \\
\text { sprinkles' }\end{array}$ & $3 \mathrm{AN}$ & g-isik & $\begin{array}{l}\text { 'sprinkle } \\
\text { him/her' }\end{array}$ \\
\hline 1PL/2PL & hisik & $\begin{array}{l}\text { ‘we/you } \\
\text { sprinkle' }\end{array}$ & 3INAN & h-isik & $\begin{array}{l}\text { 'sprinkle } \\
\text { it' }^{\prime}\end{array}$ \\
\hline 3PL & r-isik & $\begin{array}{l}\text { 'they } \\
\text { sprinkle' }\end{array}$ & REFL & $d$-isik & $\begin{array}{l}\text { 'sprinkle } \\
\text { oneself' }\end{array}$ \\
\hline
\end{tabular}

Table 6. Tetun and Bunaq prefixation of h-initial verbs.

\subsubsection{CALQUED CONSTRUCTIONS}

A "calque" is a loan-translation whereby a complex form is created in a language on the model of a complex form in a donor language. The constituents of a calque correspond semantically to the donor language constituents.

For instance, the Indonesian sentence in (3a) is made up of two clauses conjoined by dan 'and', with one verb present in each clause. The equivalent of that sentence in Alor Malay has three verbs within a single clause (3b) and instead of a prepositional phrase like ke sini 'to here' uses a verb datang 'arrive' to denote the event direction. This local Malay structure calques the event coding found in the local languages of Alor, such as Kamang (3c), which rely exclusively on series of verbs within a clause to express complex events.

Indonesian

(3) a. Saya meng-ambil buku dan mem-bawa=nyake sini.

1sG ACT-take book and ACT-carry=3SG to here.

'I get the book and bring it here.'

Alor Malay

b. Saya ambil buku bawa datang.
1sG take book carry come.

'I get the book and bring it here.' 
Kamang

c. Nal buku me wo-re sue.
1sG book take it-carry come

Bunaq has calqued several structures from Austronesian languages. I will treat here two of the most linguistically salient calques: (i) 'give' constructions, and (ii) quantifier constructions.

\subsubsection{1 'GIVE' CONSTRUCTIONS}

Languages of the Timor-Alor-Pantar family typically do not have verbs with three participants. As such, 'give' constructions which semantically involve three participants <giver, givee, gift> are formed with two verbs: (i) a verb 'take' introducing the gift, and (ii) a verb 'give to' introducing the givee and marking it with a prefix on the verb. The giver is the shared subject of both verbs. This construction is illustrated with the TAP language Kamang in (4).

\begin{tabular}{|c|c|c|c|c|}
\hline \multirow{3}{*}{ (4) } & Kamang & & & \\
\hline & $\mathrm{Nal}_{\mathrm{GIVER}}$ & $b u k u_{\mathrm{GIFT}}$ & me Markus GIVEE & $g e-n$ \\
\hline & $1 \mathrm{sG}$ & book & take Markus & 3 -give. \\
\hline
\end{tabular}

This construction is found across the TAP languages and represents the original 'give' construction for the family.

By contrast, the Bunaq 'give' construction involves only a single verb. The givee is introduced and marked by a prefix on the 'give' verb, as in the construction in (5). The gift is not introduced by a distinct 'take' verb, but follows the 'give' verb without any special marking.

Bunaq
(5) Neto $_{\mathrm{GIVER}}$
1sG Markus $\quad$ Markus $\quad$ g-ege buku $\quad$ 3AN-give book.
'I gave the book to Markus.'

This structure is unusual in that Bunaq otherwise has a strict requirement that the verb occurs in final position. It is also cross-linguistically unusual. In fact, Malchukov et al. (2010: 16) claim that the Bunaq order of elements in a 'give' construction is not attested in the world's languages. These points both strongly suggest that the Bunaq 'give' constructions has arisen through the mixing of two distinct patterns.

Indeed, looking at Bunaq's neighbours, a post-verbal position for the gift appears less unusual. In the Austronesian 'give' constructions, the giver appears before the verb and the gift directly following the verb. The givee is introduced by a preposition following the gift. This structure is illustrated 
with examples from three Austronesian languages of central Timor, (6) to (8):

Kemak

(6) $A_{\mathrm{GIVER}}$ ne buku $u_{\mathrm{GIFT}}$ le Markus MIVEE.

1SG give book to Markus.

'I gave the book to Markus.'

Tokodede

(7) $A u_{\mathrm{GIVER}}$ ne $b u k u_{\mathrm{GIFT}}$ dia Markus GIVEE.

1SG give book at Markus.

'I gave the book to Markus.'

Tetun

(8) Ha' $u_{\mathrm{GIVER}}$ fo $b u k u_{\mathrm{GIFT}}$ ba Markus GIVEE.

1SG give book to Markus.

'I gave the book to Markus.'

The Bunaq construction thus represents a partial calque of the Austronesian pattern. Bunaq preserves the original TAP pattern whereby the giver is introduced by and marked on the 'give' verb. At the same time, it mimics the Austronesian pattern by allowing three participants to one verb and by placing the gift directly after the verb.

\subsubsection{QUANTIFICATIONAL CONSTRUCTIONS}

We saw in $\S 3.1 .1$ that Bunaq has borrowed multiple numerals from its Austronesian neighbours. In this section, I discuss several quantificational (or 'quantity expressing') constructions in Bunaq which have been calqued from Tetun. Those which will be discussed here are summarised in Table 7.

\begin{tabular}{lll}
\hline Quantifier morpheme(s) & Tetun source & Bunaq calque \\
\hline 'REDUP face' & oi' $\sim$ oik & gewen $\sim$ gewen \\
'name' & naran & ginil \\
Plural pronoun & NP sia & NP hala'i \\
Dual pronoun & NP sia ruas NP & NP halali NP \\
& & \\
\hline
\end{tabular}

Table 7. Bunaq calques of Tetun quantificational constructions.

The first two quantifier constructions of Table 7 are present in Bunaq both as direct borrowings from Tetun and as calques of Tetun. The Tetun quantifier $o i^{\prime}$ oik 'all kinds of' based on a reduplication of $o i k$ 'face' (9) is borrowed into Bunaq with its quantificational (10a), but is also calqued with a reduplication 
of Bunaq gewen 'face'. Similarly, the Tetun quantifier naran, originally meaning 'name' (11), is directly borrowed into Bunaq with the meaning 'any'. The borrowing follows the Tetun word order in that it occurs before the noun (12a). A calque of the Tetun is also present with the Bunaq translation ginil 'name' following the noun. The calque is, however, made to conform to Bunaq word order, following the noun $(12 b)$.

Tetun

(9) tais oi' oik

cloth REDUP face

'all kinds of cloth.'

Bunaq

a. tais oi'oik

cloth various.kinds

b. tais gewen gewen

'all kinds of cloth.'

cloth face REDUP

'all kinds of cloth.'

Tetun

(11) naran bibi

name goat

'any goat(s).'

Bunaq
a. naran pip
name goat
b. pip ginil
'any goat(s).'
goat name
'any goat(s).'

The second two quantifier constructions of Table 7 involve pronouns. These are unique to Tetun and Bunaq in central Timor, and cannot be explained in Bunaq as having any other source than Tetun. In the first, Tetun uses the pronoun sia '3PL' to mark that the preceding noun has plural reference (13a). Bunaq calques this construction using its plural pronoun hala' $i$ '3PL' (14a). Tetun has a dual (denoting 'two' referents) coordination construction which involves sia '3PL' followed by ruas 'two' occurring between the two nouns being paired (13b). In contrast to Tetun, Bunaq has a dedicated dual pronoun halali '3Du', making the combination of hala' $i$ '3PL' plus hilo'on 'two' ungrammatical in Bunaq. As such, in calquing the Tetun dual coordination construction, Bunaq simply uses its dual pronoun in between the paired nouns (14b). 
Tetun

(13)

a. $a m a-n \quad$ sia
father-GEN 3PL
'fathers'

Bunaq

$\begin{array}{ll}\text { a. hala'i } & \text { b. eme halali ama } \\ \text { father-GEN 3PL } & \text { mother 2DU father } \\ \text { 'fathers' } & \text { 'both mother and father' }\end{array}$

\subsubsection{INCORPORATING CLAUSE-INITIAL ELEMENTS}

Native Bunaq clause coordinators occur at the end of the clause. Bunaq has also borrowed Tetun clause coordinators that occur clause-initially. Both clause-final and clause-initial coordinators can be used independently, as with be 'but' and mais 'but' in (15) and (16) respectively. In addition, the borrowed initial clause coordinators can be combined with Bunaq final ones of similar meaning. This has the effect of bracketing both ends of the dependent clause in a coordinated pair, as in (17).

(15) Hala'i so'at, bokul be.

3PL poor fat but

'They are poor but fat.'

(16) Hala'i so'at, mais bokul.

3PL poor but fat.

'They are poor but fat.'

(17) Hala'i so'at, mais bokul be.

3PL poor but fat but

'They are poor but fat.'

Such bracketing constructions illustrate a propensity found widely in the Bunaq language: rather than give up native structures in favour of foreign ones, Bunaq speakers have accommodated them alongside one another.

\subsection{SUMMARY}

Bunaq is genealogically a TAP language because there has been continuity across generations back to Proto-TAP, reflected in the forms of their bound morphemes, their pronouns, and a portion of their vocabulary. However, Bunaq speakers have en masse borrowed and adapted lexicon and grammatical constructions making it more similar to their Austronesian neighbours. As a result, the Bunaq language possesses a remarkable hybridity; it is a language in which Papuan features run deep, but one whose lexicon and constructions 
are overlayed by long and intense engagement with Austronesian language and culture.

\section{CONCLUSIONS: THE LINGUISTIC COHERENCE OF THE BUNAQ}

The modern political geography of Timor has been appreciably shaped by the Bunaq. We have seen in this paper that the drawing of the border was influenced by the changing allegiances of Bunaq polities in central Timor. The disputes eventually caused the Bunaq people to be split across the national border. What is more, since its drawing, the Bunaq have repeatedly sought refuge from conflict across the border. As a result of these displacements, the Bunaq have experienced considerable rearrangement of the settlements within their traditional lands, but also have settled in vast stretches of Austronesian territories.

Amongst the nationalist divide is cross-cut by an enduring recognition of larger group identity and a deeper remembrance of origins. The Bunaq retain a notion of their coherence as a linguistic community despite being divided by a national frontier. As the only Papuan-speaking group of central Timor, the people and their language are readily characterised as "other" both by Austronesian speakers and amongst themselves. This view has ensured that the Bunaq have remained somewhat apart, but has also led the Bunaq to borrow and adapt heavily from Austronesian language and society. The extensive cross-fertilization of lexicon and linguistic constructions that we witness in the Bunaq language confirms McWilliam's (2007) statement of "the significance of cultural hybridity on the Austronesian boundary".

\section{REFERENCES}

Adelaar, Alexander. 2005. "The Austronesian languages of Asia and Madagascar", in: Alexander Adelaar and Nikolaus Himmelmann (eds), The Austronesian languages of Asia and Madagascar, pp. 1-42. London: Curzon Press.

Berthe, Louis. 1959. "Sur quelques distiques buna' (Timor central) ", Bijdragen tot de Taal-, Land-en Volkenkunde (BKI) 115/4: 336-371.

Berthe, Louis. 1963. "Morpho-syntaxe du Bunaq (Timor central)", L'Homme Vol. 3, No. 1 (January-April): 106-116.

Boxer, Charles Ralph. 1947. The Topasses of Timor. Amsterdam: Indisch Instituut. [Mededeling No. 73, Koninklijk Instituut voor de Tropen.]

Callinan, Bernard and Nevil Shute. 1953. Independent Company: The 2/2 and 2/4 Australian Independent Companies in Portuguese Timor, 1941-1943. Melbourne: Heinemann.

CAVR. 2005. "Chega! Report of the Commission for Reception, Truth and Reconciliation in Timor Leste, Executive Summary". Commission for Reception, Truth and Reconciliation (CAVR), Dili.

Ezerman, H.E.K. 1917. “Timor en onze politieke verhouding tot Portugal sedert het herstel van het Nederlandsch gezag in Oost-Indië“, Koloniaal Tijdschrift 6/2: 865-896; 1047-1078; 1209-1232. 
Farram, Steven. 1999. "The Two Timors; The partitioning of Timor by the Portuguese and the Dutch", Studies in Languages and Cultures of East Timor 2: 38-55.

Foley, William A. 1986. The Papuan languages of New Guinea. Cambridge: Cambridge University Press.

Fox, James J. 2003. "Tracing the path, recounting the past: historical perspectives on Timor", in: James J. Fox and Dionisio Babo Soares (eds), Out of the ashes, pp. 1-27. Canberra: ANU E-Press.

Friedberg, Claudine. 1980. "Boiled woman and broiled man; Myths and agricultural rituals of the Bunaq of Central Timor", in: James J. Fox (ed.), The flow of life; Essays on Eastern Indonesia, pp. 266-289. Cambridge, Mass.: Harvard University Press.

Hägerdal, Hans. 2007. "Rebellions or factionalism? Timorese forms of resistance in an early colonial context, 1650-1769", Bijdragen tot de Taal-, Land- en Volkenkunde (BKI) 163/1: 1-33.

Heyman, Albertus. 1895. De Timor-Tractaten (1859 en 1893). PhD thesis, Leiden University.

International Court of Arbitration. 1914. "Island of Timor: Award; Boundaries in the Island of Timor; Netherlands versus Portugal". The Hague, 25 June.

Klinken, Catharina van. 1999. A grammar of the Fehan dialect of Tetun. Canberra: Pacific Linguistics.

Krieger, Heike (ed.). 1997. East Timor and the International Community; Basic Documents. Cambridge International Documents Series, Vol. 10. Cambridge: Cambridge University Press.

Malchukov, Andrej, Martin Haspelmath, and Bernard Comrie. 2010. “Ditransitive constructions: a typological overview", in: Andrej Malchukov, Martin Haspelmath, and Bernard Comrie (eds), Studies in ditransitive constructions; A comparative handbook. pp. 1-64. Berlin: De Gruyter Mouton.

McWilliam, Andrew. 2007. "Austronesians in linguistic disguise; Fataluku cultural fusion in East Timor", Journal of Southeast Asian Studies Vol. 38(2): 355-375.

Pélissier, René. 1996. Timor en Guerre; Le Crocodile et Les Portuguais (1847-1913). Paris: Pélissier.

Roever, Arend de. 2002. De jacht op sandelhout; De VOC en de tweedeling van Timor in de zeventiende eeuw. Zutphen: Walburg Pers.

Schapper, Antoinette. 2010. Bunaq, a Papuan language of central Timor. PhD thesis, Australian National University.

Schapper, Antoinette. Forthcoming. "Finding Bunaq: the homeland and expansion of the Bunaq in central Timor", in: Andrew McWilliam (ed.), Land and life in East Timor. Canberra: ANU Press.

Sowash, W. B. 1948. "Colonial rivalries in Timor", Far Eastern Quarterly 7/3: 227-235.

Stokhof, W. A. L. 1975. Preliminary notes on the Alor and Pantar languages (East Indonesia). Canberra: Pacific Linguistics. 
Swadesh, Morris. 1955. "Towards greater accuracy in lexicostatistic dating", International Journal of American Linguistics 21: 121-137.

Therik, Tom. 2004. Wehali; The Female Land: Traditions of a Timorese Ritual Centre. Canberra: Pandanus Books.

Woertelboer, W. 1955. “Zur Sprache und Kultur der Belu (Timor) ", Anthropos 50/1: 15 . 